\title{
Persepsi Jamaah Terhadap Pemberdayaan oleh Takmir Masjid di Kota Madiun Jawa Timur
}

\author{
Rosidin \\ Balai Penelitian dan Pengembangan Agama Semarang \\ nazalnifa@yahoo.co.id
}

\begin{abstract}
The article aims to analyze the level of empowerment conducted by the development committe and dimension should be prioritized. The study used quantitative research design. The validity and realibility tests remained 21 items as for being used as the research tool. The number of samples was 100 pilgrims chosen randomly. The enpowerment consisted of four dimension, namely : accesbility, participation, accountability, and local organization. The data werw analyzed using excell. The study resulted: (1) The empowerment of pilgrims in Madiun City categoryzed as good (value $=75,38$ ); (2) All the empowerment dimensions were at good levels, in whice the lowest value was found in the local organization dimension; (3) The local organization dimension value 72, 00, meant it should be priorityzed without neglecting the other dimensions,
\end{abstract}

Keywords: The level of empowerment, mosque service committe, deleop, Spiritual Living

\begin{abstract}
Abstrak
Tulisan ini menggambarkan upaya takmir masjid dalam memberdayakan jamaah dan menganalisis aspek prioritas pemberdayaan oleh takmir masjid di Kota Madiun. Pendekatan penelitian yang digunakan adalah kuantitatif. Pengujian validitas dan reliabilitas menghasilkan 21 item yang valid dan reliable untuk digunakan sebagai instrumen penelitian. Jumlah sampel yang terlibat dalam penelitian adalah 100 yang didapatkan dengan metode random sampling. Aspek pemberdayaan yang dianalisis meliputi aksesbilitas, partisipasi, akuntabilitas dan organisasi lokal. Data yang diperoleh diolah menggunakan excel. Hasil penelitian menyatakan Tingkat pemberdayaan jamaah masjid di Kota Madiun sebesar 75,38 masuk kategori baik, Semua aspek pemberdayaan yang diteliti berkategori baik. Dari keempat aspek, Organisasi Lokal mempunyai point terendah, spek pemberdayaan jamaah masjid terendah adalah pemberdayaan organisasi lokal sebesar 72,00 (baik) sebingga prioritas perbaikan, tanpa mengabaikan aspek lain
\end{abstract}

Kata kunci: Tingkat Pemberdayaan, Takmir Masjid, Membina, Kehidupan Spiritual Permalink/DOI: http://dx.doi.org/10.18326/infsl3v12i1.177-194 


\section{Pendahuluan}

Manusia diciptakan di muka bumi ini semata-mata untuk beribadah (QS. Al Dzariat: 57). Ibadah dalam suatu agama memiliki makna yang sangat luas dan menyeluruh, terutama dalam Islam, yakni menyembah, sujut, patuh dan mengabdi kepada Allah secara menyeluruh atau totalitas. Sehubungan dangan makna ibadah dalam islam, masjid memiliki multi fungsi peran yang sangat besar dalam memperbaiki moral umat Islam (Abdullah, 2003: 1). Keberadaan tempat ibadah dalam Islam sangat tidak dapat dipisahkan dari masjid, sebab masjid dikenal sebagai rumah Allah dan menjadi pusat peribadatan terutama solat lima waktu dan shalatshalat lainya. Bagi umat islam masjid sebenarnya merupakan pusat segala kegiatan. Masjid bukan hanya sebagai tempat ibadah tetapi merupakan pusat kegiatan sosial lainnya seperti: bersosialisasi, mencari ilmu, menambah wawasan dan kebudayaanmu'amalat tempat dimana lahir kebudayaan islam yang kaya dan berkah. Keadaan ini sudah terbukti mulai dari zaman Rasulullah sampai kemajuan politik dan gerakan islam di berbagai negara saat ini (Suryadi, A., 2015: 1).

Masjid merupakan tempat strategis untuk membina umat Islam. Karena keberadaan masjid merupakan manifestasi dari kemampuan dan inisiatif umat Islam. Sehingga masjid merupakan sentral aktifitas umat islam, baik dalam bidang ibadah, pendidikan, dan sosial kemasyarakatan (Suryadi, A. 2015: 3). Pada umumnya para takmir masjid hanya dipercaya mengurusi dan menjalankan tugas ketakmiran dan hanya memiliki wawasan keagamaan yang cukup, sehingga masih ada yang beranggapan bahwa masjid cukup untuk ibadah saja, sedangkan kegiatan yang lain tidak perlu.

Pada masa Nabi Muhammad SAW (Depdikbud, KBBI, hlm. 88) bahwa kedua masjid Quba dan masjid Madinah dibangun atas dasar ketaqwaan. Masjid Nabawi di Madinah telah menjabarkan fungsinya sehingga lahirlah peranan masjid dalam pemberdayaan umat yang beraneka ragam. (Suryadi, A. 2015: 2) 
Masjid dengan fungsinya yang serupa itulah yang di kembangkan, keinginan serupa yang kirannya merupakan suatu yang bukan hanya diangan-angankan melainkan merupakan sesuatu yang bisa terwujudkan bilamana bersungguh-sungguh mengusahakanya. Disini jelas bahwa peran dari takmir masjid sangatlah menentukan maju dan mundurnya aktifitas yang dilakukan oleh masjid untuk pemberdayaan jamaahnya.

Pada umumnya, masjid hanya dijadikan sebagai tempat ibadah untuk melaksanakan sholat saja, ini kurang memahami fungsi dan peran masjid. Namun ada sebagian masjid yang mulai mengembangkan itu, tetapi hanya sebagian kecil saja yang melakukanya (Suryadi, A, 2015: 4). Masjid diharapkan tidak mengandalkan sumbangan dari pemerintah. Walaupun masjid menjadi bagian dari tanggung jawab negara, tapi masjid harus belajar mandiri dengan cara memberdayakan para jamaah (Mansur Saerozy, 2015:1)

Kementerian agama sebagai leading sector dalam pembangunan agama di Indonesia memiliki tanggung jawab dalam penyelenggaraan pembangunan bidang agama (KMA) No 2 Tahun 2010), yaitu: (1) Peningkatan kualitas kehidupan beragama; (2) Peningkatan kerukunan umat beragama; (3) Peningkatan kualitas raudhatul athfal, madrasah, perguruan tinggi agama, pendidikan agama, dan pendidikan keagamaan; (4) Peningkatan kualitas penyelenggaraan ibadah haji, dan; (5) Penciptaan tata kelola kepemerintahan yang bersih dan berwibawa (KMA No.2 Tahun 2010). Perwujudan tanggung jawab tersebut khususnya poin 1 adalah melalui pembinaan kepada pengelolaan masjid agar mampu memberdayakan jamaah pada akhirnya.

Tulisan ini mengungkapkan seberapa besar Persepsi Jamaah Terhadap Tingkat Pemberdayaan dan bagaimana kontribusi variabel pemberdayaan jamaah oleh takmir masjid di Kota Madiun. Kajian ini berguna sebagai masukan bagi Penyuluh Agama Islam guna lebih meningkatkan efektifitas pembinaan masjid dalam memberdayakan jamaah dan Kementerian Agama pada umumnya. 


\section{Kajian Pustaka}

\section{Konsep Pemberdayaan}

Pemberdayaan berkembang dari realitas individu atau masyarakat yang tidak berdaya atau pihak yang lemah (powerless) baik dalam aspek pengetahuan, pengalaman, sikap, ketrampilan, modal usaha, networking, semangat, kerja keras, ketekunan dan aspek lainnya. Kelemahan berbagai tersebut mengakibatkan ketergantungan, ketidakberdayaan dan kemiskinan (M. Anwas, 2014: 48).

Pemberdayaan, Djohani (2003) adalah proses untuk memberikan daya/kekuasaan (power) kepada pihak yang lemah (powerless), dan mengurangi kekuasaan (disempowered) kepada pihak yang terlalu berkuasa (powerfull) sehingga terjadi keseimbangan. Sedangkan, Rappaport (1984), menyatakan bahwa pemberdayaan adalah suatu cara dengan mana rakyat, organisasi, dan komunitas diarahkan agar mampu menguasai atau berkuasa atas kehidupannya (M. Anwas, 2014: 49).

Kekuatan dalam konteks pemberdayaan menunjukkan kemampuan untuk menjangkau dan mengontrol sumber-sumber dan orang-orang (Fahrudin, 2012: 68). Kajian ini melihat peran takmir masjid melakukan upaya pemberdayaan berdasarkan unsurunsur pemberdayaan yaitu Aksesbilitas informasi, partisipasi, akuntabilitas dan pemberdayaan organisasi lokal.

\section{Aksesibilitas Informasi}

Aksesibiltas informasi merupakan salah satu unsur penting dalam pemberdayaan jamaah masjid. Derek Halden Concultancy (DHC, 2000) mencirikan pemahaman aksesibilitas dalam tiga pertanyaan : siapa/dimana, apa, dan bagaimana. Siapa atau di mana orang itu berada - aksesibilitas adalah bagian dari orang atau tempat. Apa peluang yang akan dicapai - fungsi tata guna lahan, aktivitas di dalamnya, atau sumber daya (termasuk orang -orang) yang memungkinkan orang itu memenuhi kebutuhan mereka. Bagaimana : faktor -faktor yang memisahkan orang -orang dengan tempat - tempat seperti jarak, waktu, biaya, informasi dan faktor 
-faktor lain yang bertindak sebagai pencegah atau hambatan untuk mengakses suatu tempat. (http://repository.usu.ac.id/bitstream/ handle/123456789/42432/Chapter\%20II.pdf;jsessionid=CED4C516 42A4903CA03078AD715618CB? sequence $=4$, dii unduh tanggal 13 Nopember 2017.

Aksesibilitas informasi, dalam kajian ini adalah aktivitas jamaah (responden) dalam mendapatkan kemudahan informasi melalui prosedur dan mekanisme yang ditetapkan oleh pengurus takmir masjid yang bersangkutan (Maksum, Dandan Lukman Buldansyah, dan Budi Prawati, 2008: 51)

\section{Partisipasi Jamaah}

Penguatan partisipasi sebagai bagian unsur tak terpisahkan dalam pemberdayaan masyarakat. Dalam Kamus Besar Bahasa Indonesia (2008), partisipasi diartikan sebagai keikutsertaan atau turut berperan serta dalam suatu kegiatan. Partisipasi juga berarti peran serta seseorang atau kelompok masyarakat secara aktif dari proses perumusan kebutuhan, perencanaan, sampai pada tahap pelaksanaan kegiatan baik melalui pikiran atau langsung dalam bentuk fisik (Y. Slamet, 1994: 7)

Hessel (2005) mengutip pernyataan Nelson yang menyebutkan adanya dua macam bentuk partisipasi, yaitu Partisipasi horizontal, yaitu partisipasi diantara sesama warga atau anggota masyarakat, di mana masyarakat mempunyai kemampuan berprakarsa dalam menyelesaikan secara bersama suatu kegiatan pembangunan. Partisipasi vertikal, yaitu partisipasi antara masyarakat sebagai suatu keseluruhan dengan pemerintah, dalam hubungan di mana masyarakat berada pada posisi sebagai pengikut atau klien. Jadi, seseorang dikatakan berpartisipasi dalam suatu kegiatan pembangunan jika individu itu benar-benar melibatkan diri secara utuh dengan mental dan emosinya, bukan sekedar hadir dan bersikap pasif terhadap aktivitas tersebut (http://digilib.uinsby. ac.id/11937/5/Bab 2.pdf, tanggal 13 Nopember 2017). Sehingga, partisipasi yang dimaksud di sini bagaimana pengurus takmir masjid melaksanakan fungsinya dalam memberdayakan jamaahnya. 


\section{Akuntabilitas}

Akuntabilitas berawal dari pemikiran bahwa, setiap kegiatan harus dipertanggungjawabkan kepada orang atau instansi yang memberi kewenangan untuk melaksanakan suatu program ( http://digilib.unila.ac.id/14662/12/BAB II.pdf, diunduh tanggal 13 Nopember 2017). Ini sejalan pendapat Haris (2007), bahwa akuntabilitas merupakan kewajiban dari individu-individu atau penguasa yang dipercayakan untuk mengelola sumberdaya publik dan yang bersangkutan dengannya untuk dapat menjawab halhal yang menyangkut kebijakan fiskal, managerial dan program ( http://digilib.unila.ac.id/14662/12/BAB II.pdf, diunduh tanggal 13 Nopember 2017)

\section{Kapasitas Organisasi Lokal}

Milen mendefenisikan kapasitas sebagai kemampuan individu, organisasi atau sistem untuk menjalankan fungsi sebagaimana mestinya secara efektif, efisien dan terus-menerus. Sedangkan Morgan merumuskan pengertian kapasitas sebagai kemampuan, keterampilan, pemahaman, sikap, nilai - nilai, hubungan, perilaku, motivasi, sumber daya, dan kondisi-kondisi yang memungkinkan setiap individu, organisasi, jaringan kerja/ sektor, dan sistem yang lebih luas untuk melaksanakan fungsi-fungsi mereka dan mencapai tujuan pembangunan yang telah ditetapkan dari waktu ke waktu. Lebih lanjut, Milen melihat capacity building sebagai tugas khusus, karena tugas khusus tersebut berhubungan dengan faktor- faktor dalam suatu organisasi atau sistem tertentu pada suatu waktu tertentu Anni (Milen, 2004: 12)

Keseluruhan definisi, pada dasarnya mengandung kesamaan dalam tiga aspek sebagai berikut: 1) bahwa pengembangan kapasitas merupakan suatu proses, 2) bahwa proses tersebut harus dilaksanakan pada tiga level/tingkatan, yaitu individu, kelompok dan institusi atau organisasi, dan 3) bahwa proses tersebut dimaksudkan untuk menjamin kesinambungan organisasi melalui pencapaian tujuan dan sasaran organisasi yang bersangkutan (Hardjanto, Imam, 2006: 8) Kapasitas organisasi lokal, Kemampuan berkerja sama, 
mengorganisir warga masyarakat, serta memobilisasi sumber daya untuk memecahkan masalah-masalah yang mereka hadapi.

Pengukuran Indeks Pemberdayaan jamaah masjid dapat di gambarkan sebagai berikut :

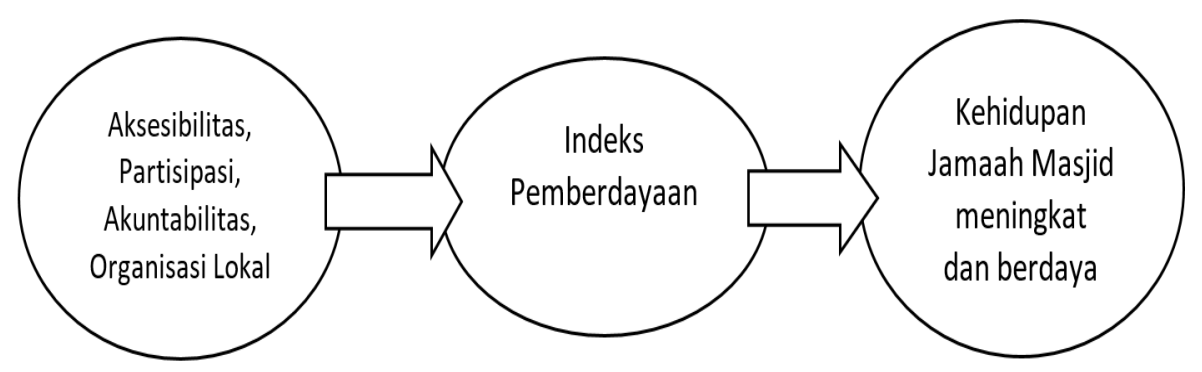

Gambar 1.

Alur Pikir Pemberdayaan Jamaah Masjid

\section{Metode Penelitian}

Pendekatan penelitian ini adalah kuantitatif. Krathwohl (1993) menyatakan bahwa pendekatan kuantitatif digunakan oleh peneliti karena data yang dikumpulkan berbentuk angka yang mencerminkan kuantitas karakteristik objek yang diamati (Rosidin, 2016: ).

Populasi penelitian adalah jamaah masjid di Kota Madiun Provinsi Jawa Timur. Sampel adalah muslim yang tergabung dalam jamaah masjid umum yang di kelola oleh masyarakat di kelurahan di Kota Madiun. Teknik pengambilan sampling adalah random sampling dimana setiap kelurahan rata-rata mengelola 1 masjid maka ada 27 masjid. Dengan asumsi minimal mempunyai 100 jamaah aktif, maka minimal terdapat 2.700 jamaah yang dapat dijangkau oleh pengelola masjid. Untuk mengetahui jumlah sampel yang dapat mewakili populasi dipakai perhitungan dengan menggunakan rumus Slovin dengan nilai kritis (batas ketelitian) sebesar 10\% (Sugiarto, 2001 : 62). Berdasarkan hasil penghitungan, diperoleh jumlah minimal sampel (N) adalah 96,42 (dibulatkan 100 sampel). Dalam penelitian ini, jumlah sampel yang digunakan sebanyak 100 jamaah masjid dari 20 masjid pada 20 kelurahan. 
Penelitian dilaksanakan di Kota Madiun Jawa Timur, khususnya di jamaah masjid yang tersebar di setiap kelurahan. Sampel diambil jamaah yang aktif hadir mengikuti kegiatan masjid, termasuk kegiatan shalat wajib. Proses pengumpulan data lapangan berlangsung dari bulan September sampai bulan Oktober 2017

Variabel Pemberdayaan Jamaah masjid dalam penelitian ini terdiri dari dimensi Aksesibilitas informasi, Partisipasi, akuntabilitas dan pemberdayaan Organisasi lokal jamaah masjid. Pengujian validitas dan relibilitas kuesioner penelitian dilakukan terhadap 42 sampel Pada pengujian validitas, batas minimal untuk menyatakan bahwa item valid adalah 0,304 .

Uji reliabilitas untuk mengetahui seberapa jauh hasil pengukuran tetap konsisten walaupun dilakukan dua kali. Pengukuran reliabilitas, Ary dkk (1985) memakai rumus Alpha dari Cronbach, yaitu mengukur butir-butir yang mempunyai multi skor, sesuai dengan ciri-ciri kuesioner tersebut yang memuat pertanyaan atau pernyataan dengan beberapa alternatif jawaban dengan rentang skor 1 - 4 (Rosidin, 2017: 84). Pengujian reliabilitas menunjukkan bahwa semua instrument pengukuran reliabel dengan koefisien Alpha Cronbach > 0,60 (Ghozali, 2006: 39). Hasil pengujian reliabilitas secara lengkap ditampilkan dalam tabel 1.

\section{Tabel 1}

Pengujian Reliabilitas Instrumen Penelitian

\begin{tabular}{|l|c|c|c|}
\hline \multicolumn{1}{|c|}{ Variabel } & N of Items & $\begin{array}{c}\text { Cronbach's } \\
\text { Alpha }\end{array}$ & Ket \\
\hline Aksesbilitas & 6 & 0,924 & Reliabel \\
\hline Partisipasi & 4 & 0,871 & Reliabel \\
\hline Akuntabilitas & 4 & 0,825 & Reliabel \\
\hline Organisasi Lokal & 7 & 0,845 & Reliabel \\
\hline
\end{tabular}

Pengolahan dan analisis data menggunakan statistik deskriptif dan inferensial. Teknik pengolahan data yang digunakan adalah menggunakan Excel dan program SPSS 20.. Proses dan analisis data sesuai dengan petunjuk dalam Keputusan MENPAN Nomor KEP/25/M.PAN/2/2004 (Rosidin, 2016: 231). 
Penelitian ini menggunakan kuesioner dengan skala Likert 4, maka kategori Pemberdayaan Jamaah Masjid disesuaikan dengan tabel Indeks KepMenpan tersebut menjadi sebagaimana tabel di bawah ini;

\section{Tabel 2}

Kategori Indeks Pemberdayaan Jamaah masjid

\begin{tabular}{|c|c|c|c|c|}
\hline No & Interval Skor & $\begin{array}{c}\text { Interval } \\
\text { konversi IPJM }\end{array}$ & $\begin{array}{c}\text { Mutu } \\
\text { Pemberdayaan }\end{array}$ & $\begin{array}{c}\text { Kinerja Takmir } \\
\text { Masjid }\end{array}$ \\
\hline 1 & $1,00-1,75$ & $25-43,75$ & D & Tidak Baik \\
\hline 2 & $1,76-2,50$ & $43,76-62,50$ & C & Kurang Baik \\
\hline 3 & $2,51-3,25$ & $62,51-81,25$ & B & Baik \\
\hline 4 & $3,26-4,00$ & $81,26-100$ & A & Sangat Baik \\
\hline
\end{tabular}

\section{Hasil Dan Pembahasan}

Deskripsi Populasi dan Sampel Penelitian

Kota Madiun Provinsi Jawa Timur memiliki 3 kecamatan, yaitu Manguharjo, Kartoharjo dan Kecamatan Taman. Masingmasing kecamatan memiliki 9 kelurahan sehingga terdapat 27 kelurahan yang merupakan pembagian induk jamaah masjid. Sampel yang digunakan dalam penelitian ini berjumlah 110 jamaah masjid yang tersebar di 20 masjid dari 20 kelurahan, sehingga ada 7 masjid dari 7 kelurahan yang tidak terambil secara acak. Pada akhir waktu pengambilan sampel hanya 100 yang mengumpulkan angket penelitian. Persebaran sampel di tiap kecamatan ditampilkan dalam tabel 2.

Tabel. 3

Jumlah Sampel di berdasarkan Kecamatan

\begin{tabular}{lcc}
\hline Kecamatan & Jumlah Sampel & Persentase (\%) \\
\hline Manguharjo & 40 & 40,0 \\
Kartoharjo & 40 & 40,0 \\
Taman & 20 & 20,0 \\
\multicolumn{1}{c}{ Total } & $\mathbf{1 0 0}$ & $\mathbf{1 0 0}$ \\
\hline
\end{tabular}


Deskripsi sampel penelitian menggambarkan karakteristik sosio demografi, yang meliputi jenis kelamin, usia, pekerjaan, pendidikan, dan kedudukan responden masjid. Gambaran lengkap sampel penelitian ditampilkan pada tabel 4 .

\section{Tabel 4}

\section{Deskripsi Sosio Demografi Sampel Penelitian}

\begin{tabular}{|c|c|c|c|c|c|}
\hline $\begin{array}{c}\text { Karakteristik } \\
\text { Sampel } \\
\end{array}$ & $\begin{array}{l}\text { Jumlah } \\
\text { (orang) }\end{array}$ & $\begin{array}{c}\text { Persen } \\
(\%)\end{array}$ & $\begin{array}{c}\text { Karakteristik } \\
\text { Sampel } \\
\end{array}$ & $\begin{array}{l}\text { Jumlah } \\
\text { (orang) }\end{array}$ & $\begin{array}{c}\text { Persen } \\
(\%)\end{array}$ \\
\hline Jenis Kelamin & & & Pendidikan & & \\
\hline Laki-laki & 87 & 87,0 & $<\mathrm{SD} /$ Sederajat & 6 & 6,0 \\
\hline \multirow[t]{3}{*}{ Perempuan } & 13 & 13,0 & SMP/Sederajat & 14 & 14,0 \\
\hline & & & SMA/Sederajat & 44 & 44,0 \\
\hline & & & Diploma/S1 & 29 & 29,0 \\
\hline Usia & & & S2 & 4 & 4,0 \\
\hline $17-31$ tahun & 7 & 7,0 & S3 & 1 & 1,0 \\
\hline $32-46$ tahun & 33 & 33,0 & Lainya & 2 & 2,0 \\
\hline $47-61$ tahun & 44 & 44,0 & & & \\
\hline \multirow[t]{3}{*}{$>62$ tahun } & 16 & 16,0 & & & \\
\hline & & & $\begin{array}{l}\text { Kedudukan } \\
\text { Responden }\end{array}$ & & \\
\hline & & & Pengurus & 47 & 47,0 \\
\hline Pekerjaan & & & Jamaah & 53 & 53,0 \\
\hline $\begin{array}{l}\text { PNS/TNI/ } \\
\text { POLRI }\end{array}$ & 19 & 19,0 & & & \\
\hline Swasta & 42 & 42,0 & & & \\
\hline BUMN/D & 2 & 2,0 & & & \\
\hline Wiraswasta & 18 & 18,0 & & & \\
\hline $\begin{array}{l}\text { Ibu Rumah } \\
\text { Tangga }\end{array}$ & 2 & 2,0 & & & \\
\hline Lainnya & 17 & 17,0 & & & \\
\hline
\end{tabular}

Sumber : Kuesioner (diolah) 
Berdasarkan tabel 4 di atas, sebagian besar sampel berjenis kelamin laki-laki (87,0\%). Hal ini dapat dipahami karena jamaah laki-laki yang sehari-hari menjalankan sholat wajib di masjid sebagaimana anjuran Rasulullah SAW sedangkan perempuan lebih utama menjalankan sholat di rumah. Dilihat dari segi usia, sebaran responden terbanyak berada pada usia dengan dominan responden berusia 47 - 61 tahun $(44,0 \%)$. Persebaran ini memberi gambaran bahwa pada rentang usia 32-46 menduduki 33\% yang akan menjadi penerus kemakmuran masjid di Kota Madiun.

Gambaran profil responden penelitian berdasarkan tingkat pendidikan menunjukkan bahwa jamaah masjid berasal dari berbagai tingkat pendidikan. Prosentase tertinggi ditemukan pada tingkat pendidikan SMA/sederajat, diikuti tingkat pendidikan Diploma/S1 dan SMP/sederajat. Selanjutnya, responden yang kebetulan menjadi pengurus takmir ada $47 \%$ sisanya jamaah masjid. Komposisi ini menunjukkan data persepsi jamaah masjid benar-benar berasal dari suara ataupun pandangan jamaah umumnya.

\section{Tingkat Persepsi Jamaah Terhadap Pemberdayaan}

Hasil penelitian Tingkat Pemberdayaan Jamaah oleh Takmir Masjid di Kota Madiun meliputi 20 masjid di 20 kelurahan masingmasing masjid 5 sampel sehingga diperoleh 100 jamaah sebagai respondennya. Adapun hasil rekapitulasi Tingkat Pemberdayaan Jamaah Masjid sebagai berikut ;

\section{Tabel 6}

\section{Pemberdayaan Jamaah menurut Aspek Aksesibilitas Informasi}

\begin{tabular}{|l|c|c|c|}
\hline \multicolumn{1}{|c|}{ Indikator } & Skor & Mutu & Kategori \\
\hline $\begin{array}{l}\text { Pengurus takmir memberikan akses } \\
\text { informasi yang merata kepada jamaah }\end{array}$ & 2,78 & B & Baik \\
\hline $\begin{array}{l}\text { Pengurus takmir menempelkan informasi } \\
\text { perkembangan kegiatan masjid pada } \\
\text { papan pengumuman yang tersedia }\end{array}$ & 3,10 & B & Baik \\
\hline
\end{tabular}




\begin{tabular}{|l|c|c|c|}
\hline $\begin{array}{l}\text { Jamaah memperoleh akses informasi } \\
\text { terhadap semua kegiatan masjid }\end{array}$ & 2,97 & $\mathrm{~B}$ & Baik \\
\hline $\begin{array}{l}\text { Informasi kegiatan diberikan kepada } \\
\text { jamaah secara transparan dan lengkap }\end{array}$ & 3,17 & $\mathrm{~B}$ & Baik \\
\hline $\begin{array}{l}\text { Informasi kegiatan masjid dapat dipahami } \\
\text { oleh jamaah }\end{array}$ & 3,04 & $\mathrm{~B}$ & Baik \\
\hline $\begin{array}{l}\text { Jamaah diperbolehkan memberikan } \\
\text { masukan untuk kegiatan yang } \\
\text { diselenggarakan oleh takmir masjid }\end{array}$ & 3,17 & $\mathrm{~B}$ & Baik \\
\hline
\end{tabular}

Sumber : data primer, diolah

Berdasar tabel di atas, maka persepsi jamaah terhadap Pemberdayaan oleh Takmir Masjid di Kota Madiun dari aspek Aksesibilitas Informasi dengan 6 indikator dapat dijelaskan ; a) Aksesibilitas Informasi Takmir masjid kepada jamaah termasuk kategori BAIK, dimana skor yang dirasakan jamaah masjid (responden) pada rentang 2,78 sampai 3,17. b) Aksesibilitas Informasi Takmir masjid tertinggi yang dirasakan jamaahnya terdapat pada indikator bahwa Informasi kegiatan diberikan kepada jamaah secara transparan dan lengkap dan Jamaah diperbolehkan memberikan masukan untuk kegiatan yang diselenggarakan oleh takmir masjid dengan skor 3,17. c) Skor terendah pada indikator bahwa Pengurus takmir memberikan akses informasi yang merata kepada jamaah sebesar 2,78. Artinya masyarakat masih merasakan kurangnya informasi yang merata kepada jamaah ketika takmir memberikan informasi masjid. d) Secara umum pemberdayaan jamaah oleh takmir masjid dari aspek aksesibilitas informasi kepada jamaah masih perlu ditingkatkan agar menjadi lebih di rasakan jamaah masjid.

Sumber daya takmir masjid dalam pemberdayaan jamaah khususnya aspek aksesbilitas informasi harus lebih di tingkatkan sebagaimana point di atas. Aksesibilitas informasi lebih beragam dan merata agar dapat dipahami jamaah dari semua kalangan. 


\section{Tabel 7}

\section{Pemberdayaan Jamaah menurut Aspek Partisipasi / Keterlibatan}

\begin{tabular}{|l|c|c|c|}
\hline \multicolumn{1}{|c|}{ Indikator } & Skor & Mutu & Kategori \\
\hline $\begin{array}{l}\text { Pengurus takmir melibatkan jamaah } \\
\text { dalam setiap kegiatan masjid }\end{array}$ & 3,52 & A & $\begin{array}{c}\text { Sangat } \\
\text { Baik }\end{array}$ \\
\hline $\begin{array}{l}\text { Pengurus mengorganisir semua bentuk } \\
\text { partisipasi jamaah dalam pengembangan } \\
\text { masjid }\end{array}$ & 3,34 & A & $\begin{array}{c}\text { Sangat } \\
\text { Baik }\end{array}$ \\
\hline $\begin{array}{l}\text { Partisipasi jamaah dalam pengembangan } \\
\text { masjid ditumbuhkan oleh pengurus } \\
\text { takmir }\end{array}$ & 3,64 & A & $\begin{array}{c}\text { Sangat } \\
\text { Baik }\end{array}$ \\
\hline $\begin{array}{l}\text { Partisipasi jamaah mengalami } \\
\text { peningkatan dari tahun ke tahun }\end{array}$ & 3,44 & A & $\begin{array}{c}\text { Sangat } \\
\text { Baik }\end{array}$ \\
\hline
\end{tabular}

Sumber : Data primer, diolah

Berdasar tabel di atas, maka persepsi jamaah terhadap Pemberdayaan oleh Takmir masjid Partisipasi atau keterlibatan di Kota Madiun dengan 4 indikator dapat dijelaskan ; a) Aspek keterlibatan atau partisipasi menurut jamaah masjid di Kota Madiun termasuk kategori Sangat Baik, dimana skor mutu layanan yang dirasakan pengguna jasa (responden) pada rentang 3,34 sampai 3,64. b) Pemberdayaan jamaah oleh takmir masjid tertinggi terdapat pada indikator bahwa Partisipasi jamaah dalam pengembangan masjid ditumbuhkan oleh pengurus takmir dengan skor 3,64; c) Skor terrendah pada indikator bahwa Pengurus mengorganisir semua bentuk partisipasi jamaah dalam pengembangan masjid sebesar 3,34. Artinya pengurus takmir masjid masih perlu meningkatkan bentuk partisipasi jamaah serta mengelolanya dengan baik sambil menggandeng jmaah/ masayarakat; d) Secara umum dari aspek partisipasi atau keterlibatan dalam pemberdayaan jamaah harus dipertahankan agar pemberdayaan yang di rasakan masyarakat tetap optimal. 
Gambaran ini menunjukan masyarakat merasakan pengurus takmir masjid di Kota Madiun sudah berbuat optimal dalam upaya melibatkan jamaahnya dalam pemberdayaan jamaah agar lebih mandiri.

\section{Tabel 8}

Pemberdayaan Jamaah menurut Aspek Akuntabilitas

\begin{tabular}{|l|c|c|c|}
\hline \multicolumn{1}{|c|}{ Indikator } & Skor & Mutu & Kategori \\
\hline $\begin{array}{l}\text { Semua kegiatan masjid dilaporkan kepada } \\
\text { jamaah secara periodik }\end{array}$ & 3,37 & A & $\begin{array}{c}\text { Sangat } \\
\text { Baik }\end{array}$ \\
\hline $\begin{array}{l}\text { Laporan pertanggungjawaban kegiatan } \\
\text { disampaikan dalam bentuk lisan maupun } \\
\text { tertulis }\end{array}$ & 3,41 & A & $\begin{array}{c}\text { Sangat } \\
\text { Baik }\end{array}$ \\
\hline $\begin{array}{l}\text { Laporan keuangan masjid dilaporkan secara } \\
\text { transparan kepada jamaah }\end{array}$ & 3,33 & A & $\begin{array}{c}\text { Sangat } \\
\text { Baik }\end{array}$ \\
\hline $\begin{array}{l}\text { Isi laporan sesuai dengan kenyataan } \\
\text { kegiatan masjid yang telah dilaksanakan }\end{array}$ & 3,47 & A & $\begin{array}{c}\text { Sangat } \\
\text { Baik }\end{array}$ \\
\hline
\end{tabular}

Sumber : Data primer, diolah

Berdasar tabel 8 di atas, persepsi jamaah terhadap Pemberdayaan dari aspek akuntabilitas yang dilakukan oleh takmir masjid di Kota Madiun dengan 4 indikator dapat dijelaskan ; a) Akuntabilitas dalam pemberdayaan jamaah termasuk kategori Sangat BAIK, dimana skor akuntabilitas yang dirasakan masyarakat/jamaah pada rentang 3,33 sampai 3,47; b) Akuntabilitas dalam pemberdayaan jamaah tertinggi terdapat pada indikator bahwa Isi laporan sesuai dengan kenyataan kegiatan masjid yang telah dilaksanakan dengan skor 3,47; c) Skor terendah pada indikator Laporan keuangan masjid dilaporkan secara transparan kepada jamaah sebesar 3,33. Artinya pengurus takmir masjid diharapkan lebih transparan dalam laporan keuangan kepada jamaahnya; d) Secara umum dari akuntabilitas dalam pemberdayaan jamaah oleh pengurus takmir masjid sudah berjalan dengan optimal sesuai harapan jamaah.

Meskipun bernilai sangat baik, keraguan jamaah perihal akuntabilitas laporan keuangan masih perlu ditingkan 
agar kepercayaan jamaah bisa bertahan. Akuntabilitas dalam pemberdayaan jamaah ini akan meningkatkan persepsi jamaahnya.

\section{Tabel 9}

\section{Pemberdayaan Jamaah menurut Aspek Organisasi Lokal}

\begin{tabular}{|l|c|c|c|}
\hline \multicolumn{1}{|c|}{ Indikator } & Skor & Mutu & Kategori \\
\hline $\begin{array}{l}\text { Jamaah mampu mendukung semua kegiatan } \\
\text { masjid }\end{array}$ & 3,40 & A & $\begin{array}{c}\text { Sangat } \\
\text { Baik }\end{array}$ \\
\hline $\begin{array}{l}\text { Jamaah masjid bergotong royong dalam } \\
\text { mendukung pelaksanaan kegiatan masjid }\end{array}$ & 1,34 & C & $\begin{array}{c}\text { Kurang } \\
\text { Baik }\end{array}$ \\
\hline $\begin{array}{l}\text { Pengurus takmir mampu memberdayakan } \\
\text { potensi masyarakat / jamaah }\end{array}$ & 2,99 & B & Baik \\
\hline $\begin{array}{l}\text { Sumber dana masjid dikelola untuk } \\
\text { pemberdayaan ekonomi jamaah }\end{array}$ & 1,38 & D & $\begin{array}{c}\text { Tidak } \\
\text { Baik }\end{array}$ \\
\hline $\begin{array}{l}\text { Sebagian sumbangan jamaah digunakan } \\
\text { untuk pelaksanaan pendidikan yang } \\
\text { diselenggarakan masjid }\end{array}$ & 1,69 & D & $\begin{array}{c}\text { Tidak } \\
\text { Baik }\end{array}$ \\
\hline $\begin{array}{l}\text { Bentuk sumbangan masyarakat diorganisir } \\
\text { dengan baik oleh pengurus takmir }\end{array}$ & 3,23 & B & Baik \\
\hline $\begin{array}{l}\text { Jamaah merasa puas atas kerjasama yang } \\
\text { dibangun antara jamaah dengan pengurus } \\
\text { takmir }\end{array}$ & 2,53 & B & Baik \\
\hline
\end{tabular}

Sumber : Data primer, diolah

Tabel 9 di atas, menunjukkan bahwa maka pengurus takmir masjid dari aspek organisasi lokal dalam usaha memberdayakan jamaahnya di Kota Madiun dengan 7 indikator dapat dijelaskan ; a) Persepsi jamaah masjid terhadap pemberdayaan organisasi lokal oleh pengurus takmir masjid termasuk kategori BAIK, dimana skor yang dirasakan jamaah masjid pada rentang 1,38 sampai 3,40; b) Pemberdayaan organisasi lokal tertinggi terdapat pada indikator bahwa pengurus takmir berhasil memberdayakan sehingga Jamaah mampu mendukung semua kegiatan masjid dengan skor 3,40; c) Skor terendah pada indikator bahwa Sumber dana masjid dikelola untuk pemberdayaan ekonomi jamaah sebesar 1,38. 
Artinya menurut jamaah masjid bahwa pengurus takmir masjid belum mengoptimalkan pengelolaan dana masjid untuk kegiatan pemberdayaan ekonomi jamaah melalui penguatan organisasi lokal yang ada; d) Secara umum dari aspek pemberdayaan organisasi lokal usaha yang telah dilakukan pengurus takmir masjid dari pandangan jamaahnya masih perlu di tingkatkan.

Masyarakat sepenuhnya yakin bahwa pengurus takmir masjid akan berusaha melakukan upaya agar program yang dijalankan bermanfaat bagi jamaahnya. Program pemberdayaan ekonomi dan pendidikan bagi jamaah masjid menduduki skor yang rendah Artinya Pengurus takmir masjid masih perlu lebih berusaha maksimal agar kegiatan takmir masjid lebih menyentuh kebutuhan jamaah secara berkelanjutan.

\section{Kontribusi Aspek Pemberdayaan Jamaah Masjid}

Tingkat Pemberdayaan Jamaah oleh Takmir Masjid di Kota Madiun dapat di baca seperti pada tabel di bawah ini :

\section{Tabel 10}

Tingkat Pemberdayaan Jamaah Masjid di Kota Madiun

\begin{tabular}{|c|l|c|c|c|c|c|}
\hline No & \multicolumn{1}{|c|}{ Indikator } & $\begin{array}{c}\text { Nilai } \\
\text { unsur }\end{array}$ & $\begin{array}{c}\text { Nilai } \\
\text { Standar }\end{array}$ & $\begin{array}{c}\text { Tingkat } \\
\text { Pemberdayaan }\end{array}$ & Mutu & $\begin{array}{c}\text { Kategori } \\
\text { Pemberdayaan }\end{array}$ \\
\hline 1 & Aksesibilitas & 3,04 & 25 & 76,00 & B & Baik \\
\hline 2 & Partisipasi & 3,01 & 25 & 75,25 & B & Baik \\
\hline 3 & Akuntabilitas & 3,13 & 25 & 78,25 & B & Baik \\
\hline 4 & Organisasi Lokal & 2,88 & 25 & 72,00 & B & Baik \\
\hline & $\begin{array}{c}\text { Indeks } \\
\text { Pemberdayaan }\end{array}$ & & & 75,38 & B & Baik \\
\hline
\end{tabular}

Sumber : data primer (diolah)

Berdasarkan kriteria yang telah ditentukan di atas, maka Tingkat Pemberdayaan Jamaah oleh Takmir Masjid di Kota Madiun sebesar 75,38 dimana point tersebut pada rentang 62,51-81,25 termasuk dalam kategori BAIK. Artinya, Pengurus Takmir Masjid masih perlu berusaha keras agar semua dimensi pemberdayaan tersebut tercapai lebih baik lagi. Angka tersebut juga dapat diartikan 
bahwa jamaah masjid masih mengharapkan sentuhan inovasi yang lebih mengarah pada pemberdayaan jamaah masjid dari semua aspek secara menyeluruh.

\section{Kesimpulan}

Kesimpulan hasil penelitian berdasarkan data di atas adalah : 1) Tingkat Pemberdayaan Jamaah oleh pengurus Takmir Masjid di Kota Madiun sebesar 75,38 point, masuk dalam kriteria pemberdayaan jamaah masjid BAIK; dan 2) Aspek organisasi lokal mempunyai skor paling rendah $(72,00)$ sehingga menjadi prioritas peningkatan pemberdayaan tanpa mengabaikan aspek lainnya.

Sehingga perlu upaya konkret dalam membantu meningkatkan pemberdayaan yang dilakukan pengurus Takmir Masjid kepada jamaahnya /masyarakat, antara lain : 1) Perlu upaya pelatihan kepada pengurus takmir masjid terkait pengelolaan dan pemberdayaan umat terutama ekonomi dan pendidikan bagi jamaah agar aksesibilitas, Partisipasi, akuntabilitas, dan pemberdayaan organisasi lokal masyarakat lebih meningkat bagi jamaahnya; 2) Pengambil kebijakan pada Kementerian Agama hendaknya merespon dan memenuhi serta memperbaiki aspek-aspek pemberdayaan yang masih rendah dalam upaya meningkatkan tugas dan fungsinya secara terprogram dan berkelanjutan.

\section{Daftar Pustaka}

Anni Milen, 2004. Pegangan Dasar Pengembangan Kapasitas. (terjemahan). Yogyakarta: Pondok Pustaka Jogja,

Arif Suryadi, Arif. 2015. Pemberdayaan Ekonomi Jamaah Masjid Nurul 'Ashri Catur Tunggal Depok Sleman, Skripsi. Yogyakarta: Jurusan Pengembangan Masyarakat Islam Fakultas Dakwah dan Komunikasi Universitas Islam Negeri Sunan Kalijaga

Dokumen Kep. Men. Pan No. KEP/25/M.PAN/2/2004 tentang Pedoman Umum Penyusunan Indeks Kepuasan Masyarakat Unit Pelayanan Instansi Pemerintah.

Fahrudin, Adi, 2012. Pengantar Kesejahteraan sosial. Bandung: PT. Refika Aditama 
Ghozali, Imam, 2006. .Aplikasi Analisis Multivariate Dengan Program SPSS. Semarang: Badan Penerbit Universitas Diponegoro Semarang

Imam Hardjanto, 2006. Pembangunan Kapasitas Lokal (Local Capacity Building). Malang: Program Pascasarjana Universitas Brawijaya

Keputusan Menteri Agama No. 2 Tahun 2010 tentang Rencana Strategis Kementerian Agama tahun 2010-2014

Krathwohl, D.R. 1993. Methods of Educational and Social Sience Research: An Integrated Approach. New York: Longman

Mansur Saerozy, 2016, Jadikan Masjid Sentral Pemberdayaan Jamaah. dalam Ahmad Muhajir. JURNAS.COM pada : http:// www.jurnas.com/artikel/11559/Jadikan-Masjid-SentralPemberdayaan-Jamaah/, tanggal 07 Nopember 2017

Maksum, Dandan Lukman Buldansyah, dan Budi Prawati, 2008. Aksesibilitas Informasi, Intensitas Komunikasi, dan Efektivitas Layanan Informasi Digital. Dalam Jurnal Perpustakaan Pertanian Vol. 17, Nomor 2, 2008

M. Anwas, Oos, 2014. Pemberdayaan Masyarakat Di Era Global. Jakarta: Alfabeta, CV

Rosidin, 2016. Indeks Budaya Kerja Dalam Pelayanan Pernikahan Di Kabupaten Banyumas, dalam Jurnal Dialog Vol. 39 No. 2 Jakarta: Badan Litbang dan Diklat Kementerian Agama RI

Rosidin, 2017. Indeks Peran Penyuluh Agama Dalam Membina Kehidupan Beragama Keluarga Majelis Taklim Di Kabupaten Sragen Jawa Tengah, dalam Jurnal Smart Vol. 3 No. 1 Semarang: Balai Penelitian dan Pengembangan Agama Semarang

Sugiarto, 2001 dalam http://thesis.binus.ac.id/Doc/Bab3/2011-100485-mn\%203.pdf, diunduh tanggal 19 Pebruari 2017

Supriyanto Abdullah, 2003. Peran dan Fungsi Masjid.Yogyakarta: Cahaya Hikmah

Y. Slamet, 1994. Pembangunan Masyarakat Berwawasan Partisipasi, Surakarta : Sebelas Maret University Press 